\title{
DESIGN OF KOST RENT INFORMATION SYSTEM
}

\author{
Lydia Salvina Helling ${ }^{1}$, Hasanudin ${ }^{2}$, Endang Wahyudi ${ }^{3}$, A.A.Gede Ajusta ${ }^{4}$ \\ ${ }^{1}$ Sistem Informasi Akuntansi , 2 Akuntansi, ${ }^{3}$ Sistem Informasi Akuntansi, ${ }^{4}$ Sistem Informasi \\ 1,2,3,4 Universitas Bina Sarana Informatika \\ www.bsi.ac.id \\ ${ }^{1}$ lydia.lsh@bsi.ac.id, ${ }^{2}$ hasanudin.hnu@bsi.ac.id, ${ }^{3}$ endang.edw@bsi.ac.id, ${ }^{4}$ a.gede.age@bsi.ac.id
}

\begin{abstract}
Abstrak
Rumah Kost Hj.Gaby adalah salah satu dari sekian banyak rumah kost yang disewakan sekitar kawasan industri dan perkantoran wilayah Tg.Priok, Jakarta Utara. Rumah kost ini masih mempergunakan papan di depan rumahnya untuk menandakan bahwa rumah tersebut disewakan untuk kost. Cara ini kurang efektif dalam mempromosikan rumah kost tersebut karena calon penyewa harus dengan tidak sengaja lewat dan melihat papan promosi. Pembayaran uang muka sewa kost dan bulanananya pun masih harus bertemu langsung dengan pemilik kost sehingga memerlukan waktu khusus. Sistem Informasi Sewa Kost yang dirancang ini diharapkan akan membantu calon penyewa ataupun penyewa lama untuk melakukan transaksi pemesanan dan pembayaran dengan lebih praktis, selain membantu pemilik kost dalam merapikan manajemen penyewaan kamar kostnya. Metode yang digunakan dalam penelitian ini yaitu: wawancara, observasi, dan studi lierasi untuk pengumpulan datanya. Sedangkan model yang digunakan untuk pengembangan perangkat lunak mempergunakan Rapid Application Development (RAD) Model. Hasil penelitian ini diharapkan dapat membantu pemilik kost dalam mempromosikan rumah kostnya dan juga menyediakan cara yang lebih efektif dalam beberapa transaksi yang berhubungan dengan rumah kost tersebut.
\end{abstract}

Kata kunci: Sistem Informasi; Rapid Application Development; Penyewaan; Promosi

\begin{abstract}
Rumah Kost Hj. Gaby is one of the many boarding houses for rent around industrial areas and offices in the Tg. Priok area, North Jakarta. This boarding house still uses a board in front of the house to indicate that the house is rented out for boarding. This method is less effective in promoting the boarding house because prospective tenants must accidentally pass and see the promotion board. The down payment for boarding and monthly rent still has to meet directly with the owner of the boarding house so that it requires special time. The boarding rental information system that is designed is expected to help prospective tenants or tenants to make more practical order and payment transactions, in addition to helping boarding owners tidy up their boarding room rental management The methods used in this research are: interviews, observation, and literacy studies for data collection. Meanwhile, the model used for software development uses the Rapid Application Development Model (RAD). The results of this study are expected to assist boarding owners in promoting their boarding houses and also provide a more effective way of conducting transactions related to the boarding houses.
\end{abstract}

Keywords: Information Systems; Rapid Application Development; Rental; Promotion

\section{INTRODUCTION}

Humans, living in this world have basic needs that must be fulfilled every day. The basic needs include the need for Clothing, Food, and Board (Biantoro \& Purnomo, 2017). Clothing means the need for clothing or covering or body armor. Food means the need for food. Board means the need for a place to live or shelter (Susanti et al., 2018).

In big cities in Indonesia, the basic needs of housing are needed by residents as a resting place after they return to work (Sudiyono, 2015), activity or make a living all day long. The need for boards is not only needed by the natives of the city but is also needed by some workers who make a living in the city and are forced to stay temporarily to save on transportation costs or time so they can return the next day to work. (Rachmawati, 2017). Some housing alternatives are usually offered for rent in cities that are central to the driving force of the regional economy, ranging from those with relatively low prices such as boarding houses, rented houses, and guesthouses, to high-priced ones such as apartments and hotels. 
A boarding house or boarding house is one of the places to provide lodging services or temporary living quarters consisting of several rooms and each room has several facilities offered and the price has been determined by the boarding house owner, while the length of the rental period is determined by the room tenant. (Ratnasari et al., 2018). A boarding house is an alternative place to live where the rental fee is not too expensive, it feels "homey" (Werdiningsih et al., 2015) and easy to maintain. On that basis, boarding room rental services are currently one of the promising business fields by utilizing rooms or houses that are rarely used for rent, especially if the location where the boarding house is close to an office or campus environment. (Sabirin \& Sulfia, 2018).

The need to search for boarding houses by the wishes of tenants is currently lacking because there are not many information systems available that present this. (Fatkhudin \& Novianti, 2015). Constraints that also occur when a prospective boarding house tenant already feels that they are compatible with the boarding house offered and wants to immediately book the boarding room, the prospective tenant must make an appointment with the owner of the boarding house and pay a down payment when the meeting occurs. This is sometimes felt to be less effective and efficient in matching the meeting time of boarding house owners with prospective boarding tenants due to the busyness of each party. (Budiman et al., 2019). Likewise, when the tenant wants to make a payment every month by submitting it directly to the owner of the boarding house, so the tenant has to wait for the owner to arrive at the boarding house. These reasons are the background for researching to develop a system that is now running as a boarding rental information system.

In previous research, users or members are given access rights in the search process, view, and select boarding houses that are of interest, and can register on the form provided by the system. Users or members can also see in detail the boarding house for rent (Syam, 2018). Another research also discusses the customer can register and login to then be able to rent a boarding house. The rental is checked by the system admin and validated, then approved by the owner. The customer then uploads his data and can hold a meeting to give the boarding house keys (Sianturi et al., 2018).

This research will provide a solution for the design of an online boarding rental information system via the website. The design will include the provision of facilities for prospective boarders in registration and payment of rental advances. Prospective renters can also see in detail the conditions of the boarding room they are going to rent through the boarding room page which displays various angles of the boarding room. Old boarding house tenants can also enter their monthly boarding payment transactions accompanied by proof of transfer. Boarding owners can also manage boarding rental management and print rental reports and boarding payments that have occurred.

\section{RESEARCH METHODS}

The research method used is an experimental model that starts with an analysis of the current system, then develops it into a better information system according to needs.

\section{Types of research}

The procedural model used in this study has descriptive properties that produce certain products.

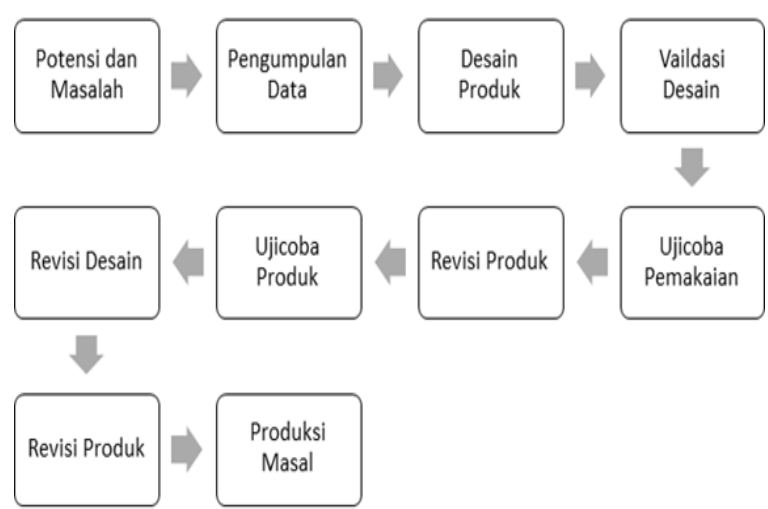

Source : (Hanafi, 2017)

Figure 1.Research and Development (R\&D)

Model

This model adapts Borg and Gall's research and development model which will produce a product and test the product's effectiveness. (Haq, 2016). This study aims to develop a boarding rental system that is still manual in terms of management and information retrieval related to boarding room rentals. This research will produce a website-based boarding rental information system that is easily accessible to many people, especially boarding seekers from among workers and students or students. This Boarding Rental Information System will also help boarding house owners promote their boarding houses and increase efficiency and effectiveness from the management side. 


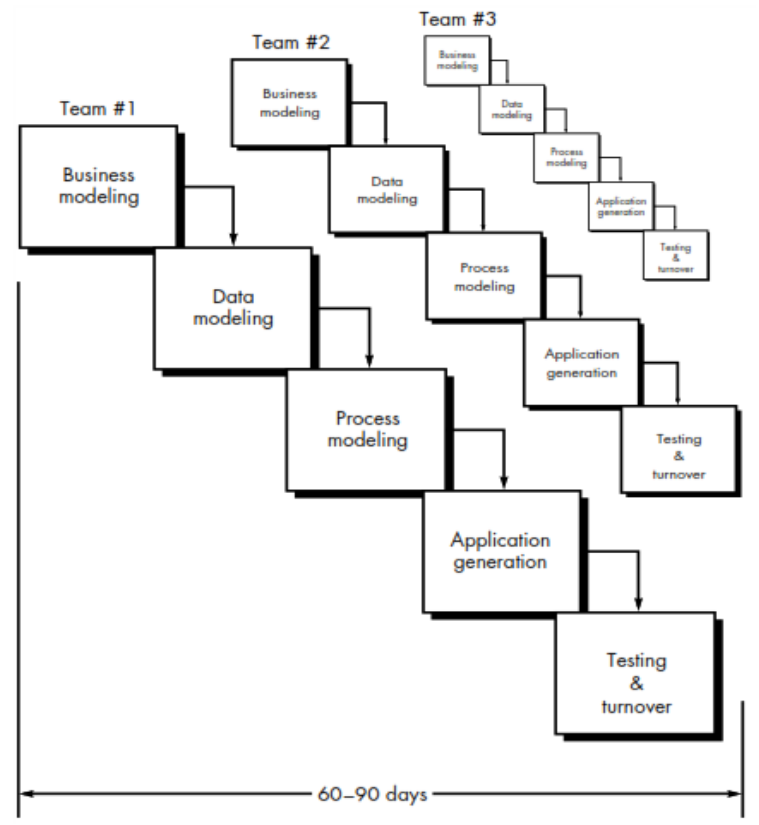

Source : (Pressman, Roger S, 2012)

Figure 2. Rapid Application Development (RAD)

Meanwhile, the software development method applied in this study uses the Rapid Application Development (RAD) type System Development Life Cycle (SDLC) which is relatively more in line with the conditions faced in the development of this system. RAD requires only a small scope and involves only a small team (Kusaeri et al., 2018) and the development process is relatively short (Kusaeri et al., 2018).

The steps in the RAD are as follows: (Irnawati \& Listianto, 2018)

1. Business Modeling

Modeling is done to model business functions to find out what information should be made, who should make the information, how the information flows, what processes are related to that information.

\section{Data Modeling}

Model what data is needed based on business modeling and define the attributes and their relationships with other data

3. Process Modeling

Implement defined business functions related to defining data.

4. Making Applications

Implementing process and data modeling into a program. The RAD model strongly encourages the use of existing components where possible.

5. Testing and Substitution

Testing the components that are made, if it is tested, the component development team can move on to develop the next component.

\section{Time and Place of Research}

This research took place at the rental boarding house, Mrs. Hj. Gaby, which is located at Jl.Kramat Jaya Gang III Blok X No: 35, Semper-Tg.Priok, North Jakarta. Rumah Kost Ibu $\mathrm{Hj}$. Gaby is one of the many boarding houses located around industrial areas, such as PT. KBN (Kawasan Berikat Nusantara), PT.Pelindo, NPCT1 (New Priok Container Terminal One), and several other business centers. Rumah Kost Ibu Hj. Gaby is a house that was founded in 1983 and is an old building which has 2 floors. The 1 st floor is occupied by Mrs. Hj. Gaby and her 2 daughters, while the 2 nd floor which has 1 bedroom is occupied by a son from Mrs. Hj. Gaby. The second floor also has a large space that is used by Mrs. Hj. Gaby's husband, who works as a high school teacher, to conduct private lessons. Since Mrs. Hj. Gaby's children got married and had their own houses, these rooms were empty. Likewise, when Mrs. Hj. Gaby's husband passed away, the large space on the 2nd floor was not used. Mrs. Hj. Gaby then took the initiative to rent out rooms on the 2nd floor for boarding for female employees who work in the industrial and business areas.

The research was conducted during a visit to Mrs. $\mathrm{Hj}$. Gaby's boarding house by conducting interviews about the rental procedure and payment of boarding rent each month.

\section{Research Targets or Targets}

Prospective tenants, tenants, and boarding house owners are the object of this research in obtaining accurate information related to the data collection stage so that the resulting information system product will provide benefits and benefits to the parties concerned.

\section{Procedure}

The procedure of the boarding room rental system currently being implemented by Mrs. Hj. Gaby is as follows:

1. Room Booking Procedure

Prospective renters of boarding rooms will come to the boarding house to see for themselves the condition of the boarding room and the facilities provided by the boarding house owner. If the prospective renters of a boarding house feel that they are compatible with the existing conditions and facilities and the applicable regulations, the prospective tenant will submit a photocopy of their KTP, KK, and down payment of the rental transaction. The owner of the boarding 
house then records the down payment in the boarding book and keeps a photocopy of the KTP and KK. The down payment will deduct the monthly rental fee that will be paid after one month the tenant occupies the boarding room.

2. Boarding Rental Payment Procedures

The new border will pay off his boarding fee after one month of stay. Meanwhile, the tenants of the old boarding house will pay the rent at the end of each month. Payment is made by handing over the rent directly to the boarding house owner. The rent for boarding includes the cost of using electricity and water. All boarding rental transactions along with the payment are recorded by the owner of the boarding house in the boarding book.

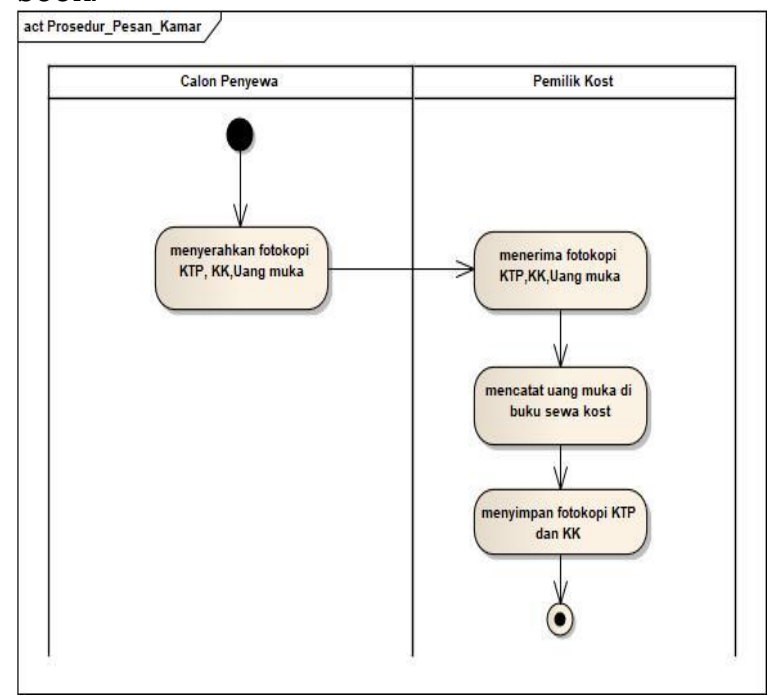

Figure 3.Activity Diagram of the Running System in the Room Booking Procedure

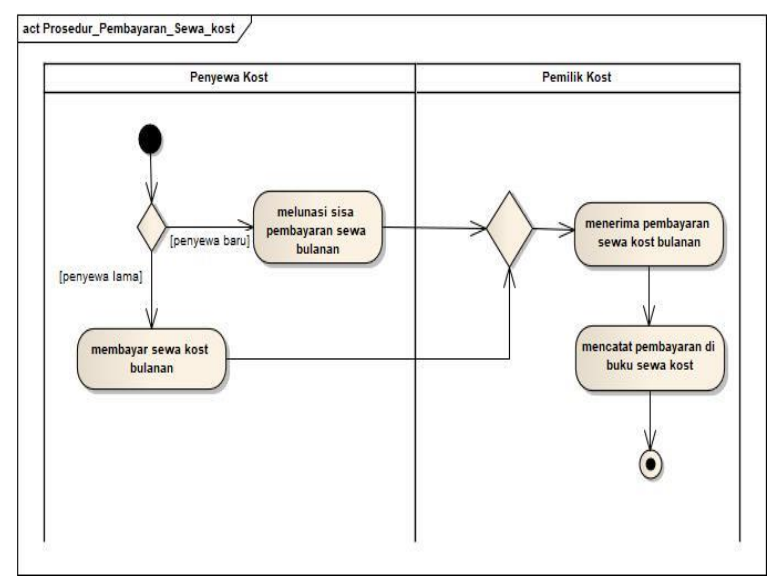

Figure 3.Activity Diagram of the Running System in the Room Booking Procedure

\section{Data Collection Techniques}

In this study, the data collection process was carried out in a way:

1. Direct observation / Observation
Researchers observed directly the procedures that occurred in the boarding room rental system at $\mathrm{Hj}$. Gaby's boarding house.

2. Interview

Researchers conducted questions and answers with the boarding house owner, Hj. Gaby, to get accurate information related to the boarding room rental system at the house. The results of the interview then resulted in the need for a boarding rental information system that was more effective and efficient with the circumstances faced by boarding house owners.

3. Literature study

Journals that discuss the development of rental information systems are reliable sources in this research. Besides, books related to information systems are also very supportive of the required information system design and analysis stage.

\section{Data analysis technique}

Base on the data collected through direct observation of the current system, along with interviews with boarding house owners, the problems faced by boarding house owners can be described, namely:

1. The boarding house rental system that is currently running is felt to be less supportive of the boarding house promotion because prospective tenants can only find out the information when looking directly around the location where there are many boarding houses.

2. Prospective tenants must come to the boarding house location to see for themselves the condition of the boarding house to be rented along with the facilities provided by the boarding house owner.

3. The process of booking boarding rooms and paying the down payment for rent is done offline, meaning that prospective tenants must meet directly with the owner of the boarding house to make the initial rental transaction.

4. The process of paying boarding fees per month is still done face to face with the boarding house owner.

5. The recording of boarding room rental transactions and monthly rental payments are made in the boarding rental book.

\section{RESEARCH RESULTS AND DISCUSSION}


The next stage is to carry out each step in the Rapid Application Development (RAD) Model, namely :

\section{Business Modeling}

In the analysis process, several needs have generated that change the current system so that a more systematic design proposal is made and is expected to solve problems in the field. The proposed boarding room rental system procedure consists of :

\section{Procedure for booking a room}

Prospective tenants will visit the website of the boarding rental information system owned by Hj.Gaby. After seeing the room conditions and facilities shown in the photos of each room for rent, the prospective tenant registers as a member of the information system website. Prospective tenants will upload the requested KTP and KK on the member registration form. After that, prospective tenants must also make payment transactions by transferring the down payment for the rent for the boarding house and uploading the proof of the advance payment on the Payment form. Prospective tenants will also be directed to contact the boarding owner's contact number on the website to make an appointment to visit the boarding house.

2. Boarding Rental Payment Procedures

Prospective renters who have been approved by the owner of the boarding house will pay the first payment for the rent on the Payment Form by uploading proof of transfer after the prospective tenant has lived for 1 month. Meanwhile, payment for boarding rent for old tenants is made at the end of the month by filling in the same form.

3. Reporting Procedure

Boarding house owners can view or print reports related to the down payment transaction process, monthly boarding rental payments, and boarding tenant data.

\section{Data Modeling}

At this stage, there will be a database design which is the result of an analysis of the proposed system requirements. The design of this database uses the Entity-Relationship Diagram to find out what tables are needed and the relationships between these tables. Figure 4 outlines what tables are in the boarding rental information system design and the relationships between these tables.

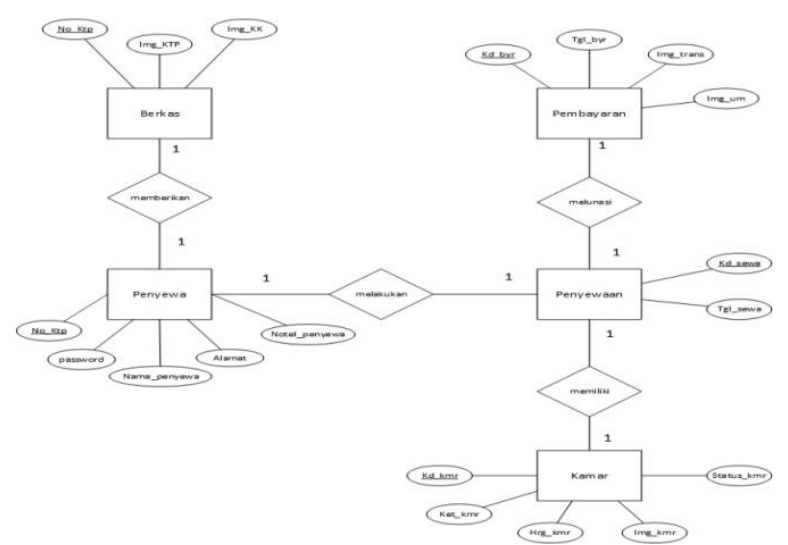

Figure 4. ERD Proposed System

The ERD formed in Figure 4 is the basis for forming the Logical Record Structure by paying attention to its cardinality so that the LRS transformation will be formed as shown in Figure 5.

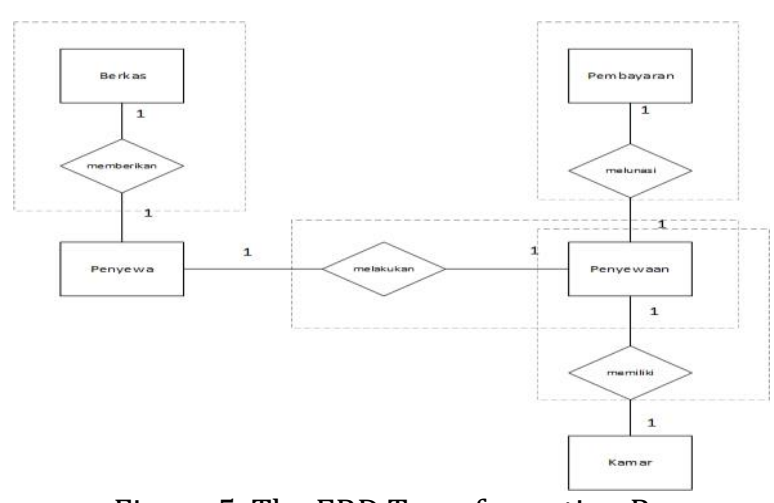

Figure 5. The ERD Transformation Process into LRS

In the process of transforming ERD into LRS, cardinality in ERD plays an important role in determining the direction of merging one entity to another.

Explanation :

1. In the relationship between the Tenant entity and the File entity that has a cardinality of 1 : 1 , the direction of incorporation to the File entity is because the Tenant entity is needed in the File entity

2. In a relationship between the Leasing and Leasing entities which has a cardinality of $1: 1$, the direction of incorporation to the Leasing entity is because the Leasing entity is required by the Leasing entity

3. In the relationship between the Leasing entity and the Chamber entity that has a cardinality of 1: 1 , the direction of incorporation into the Leasing entity is because this entity requires the Room entity.

4. In the relationship between the Leasing entity and the Payments entity that has a 
cardinality of 1: 1 , the direction of incorporation into the Payments entity is because this entity requires the Leasing entity.

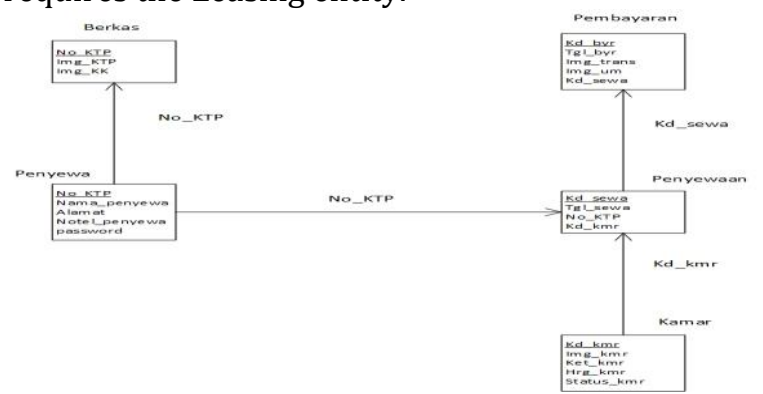

Figure 6. LRS Database Design

Figure 6 illustrates the results of the ERD to LRS transformation process. Figure 7 describes the Class Diagram which is formed from the associations between classes in the design of the boarding rental system.

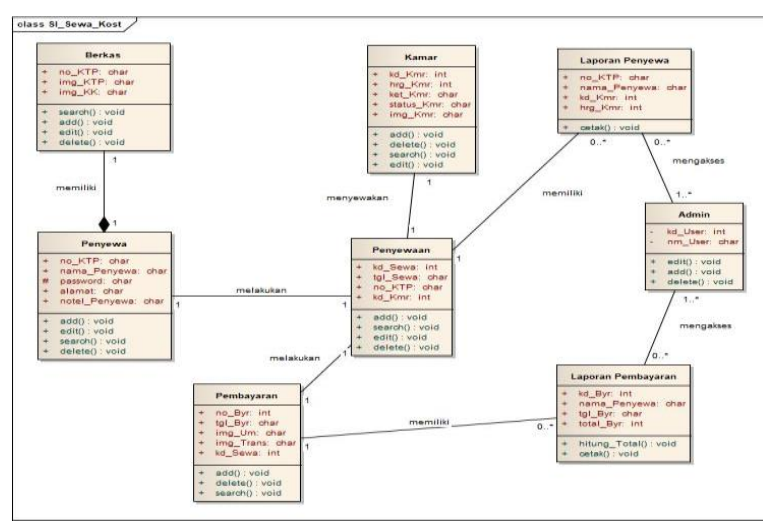

Figure 7. Class diagram of the proposed boarding rental system

\section{Process Modeling}

At this stage, it is explained in the picture about what facilities are provided by the boarding rental system from the needs of prospective tenants, tenants and boarding owners, as seen in Figure 8, Figure 9, and Figure 10.

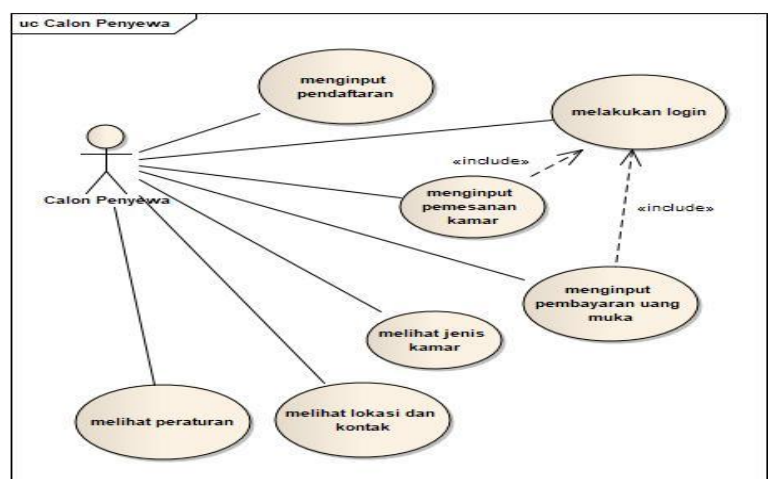

Figure 8. Use Case Diagram of the Proposed System for Prospective Tenants
In Figure 8, prospective tenants will have a look at the room conditions and facilities provided by the $\mathrm{Hj}$. Gaby boarding house by accessing the room page. Prospective tenants can also see the location of the boarding house and the contact number of the boarding house owner on the location and contact page. On this page, there are google maps facilities to see the location and address of the boarding house. After the prospective tenant feels comfortable with the boarding room offered, the prospective tenant can register first before finally using the access right in the form of an ID card number and password to make any advance payment. Prospective tenants can also read the rules that apply to the boarding house.

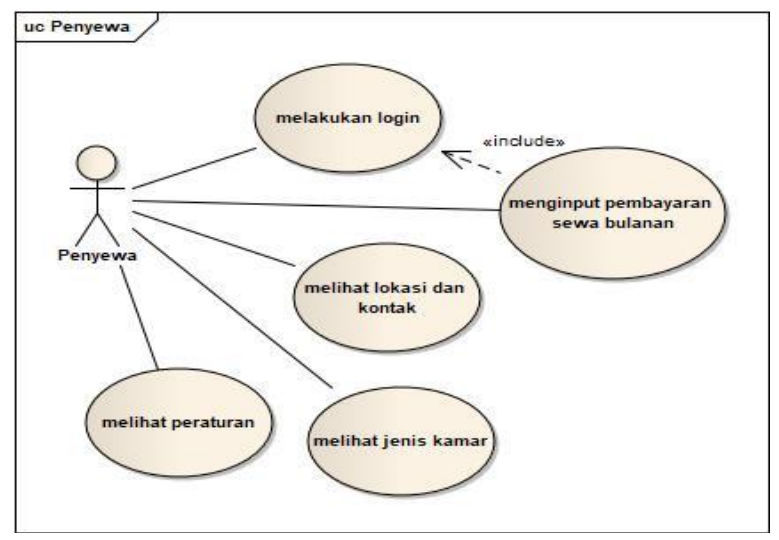

Figure 9. Use Case Diagram of the Proposed System for Tenants

Figure 9 describes the facilities provided by the boarding rental information system for tenants who have lived for a long time. In addition to basic facilities such as viewing regulations, logging in, viewing locations and contacts, viewing room types, old tenants can also input monthly rental payments on this website.

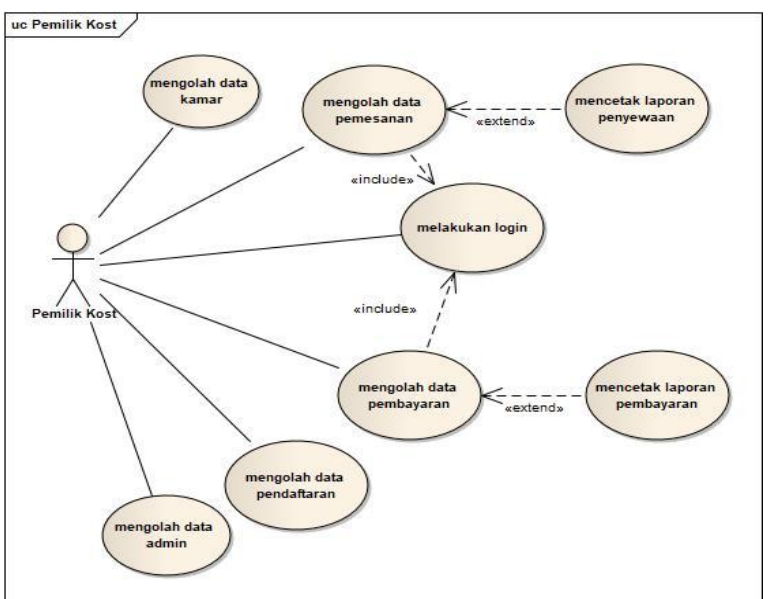

Figure 10. Use Case Diagram of the Proposal System for Boarding Owners 
Figure 10 explains what can be obtained from this website-based boarding rental information system. Boarding owners can process room data, process admin data, process registration data, process payment data, process room reservation data, besides that, they can view or print rental reports and boarding payment reports every month.

\section{Application generation}

Website display design for users is made at this stage.

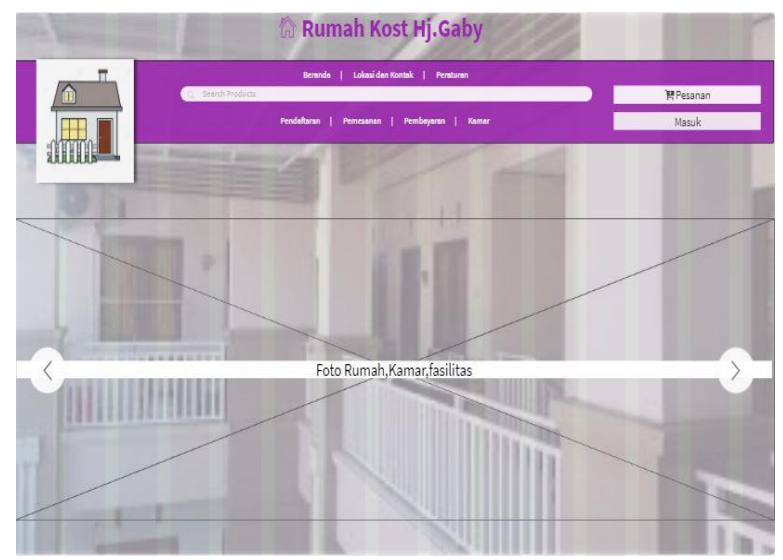

Figure 11. Home page design

Figure 11 shows the design of the home page that the boarding house website $\mathrm{Hj}$. Gaby will have. On this page there will be a menu for registration, payment, location, and contact, applicable regulations, ordering

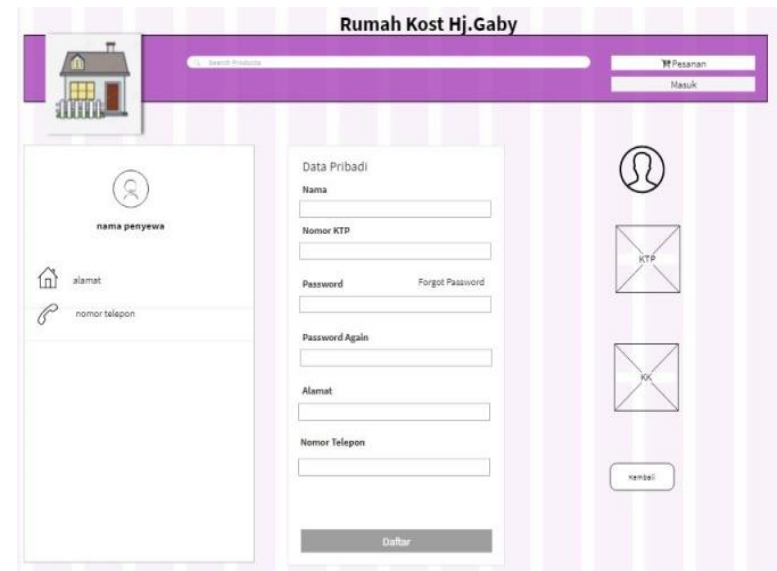

Figure 12. The design of the Registration page for Prospective Tenants

Figure 12 describes the page design for registering for prospective tenants who are interested in renting a room at $\mathrm{Hj}$. Gaby's boarding house.

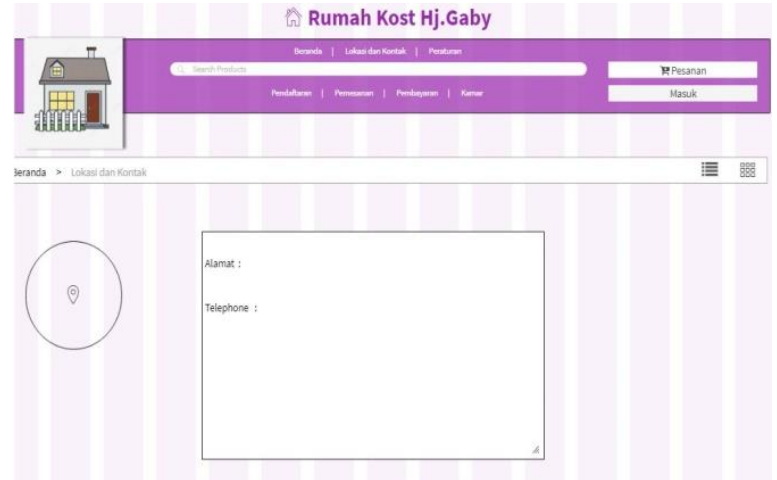

Figure 13. Location and Contact page design

Figure 13 illustrates the location and contact page of the following $\mathrm{Hj}$. Gaby boarding house with the position of the boarding house on google maps.

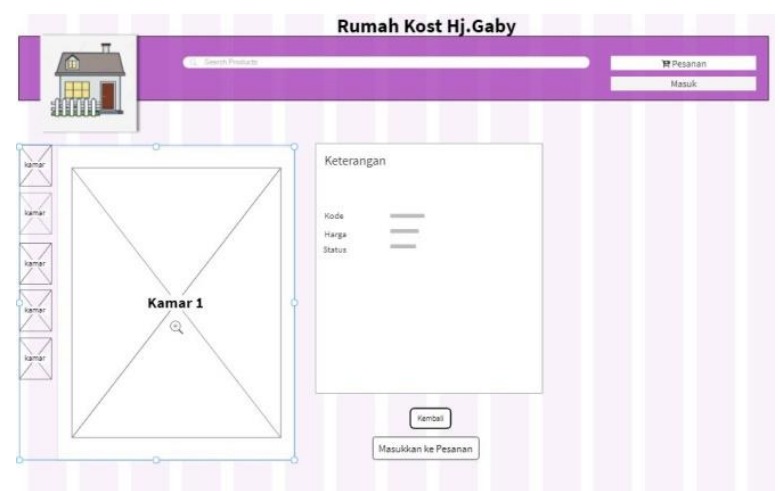

Figure 14. Room Details page design

Figure 14 explains the page design for a room that contains information about room conditions, room rates, and photos that showroom conditions from various angles.

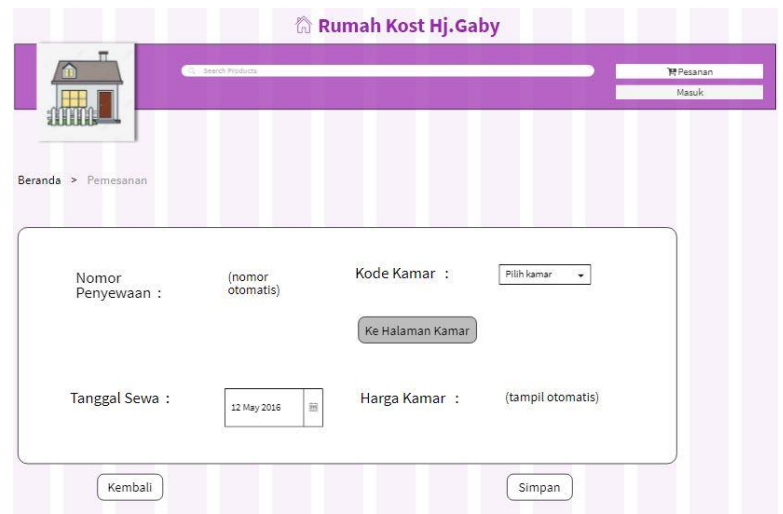

Figure 15. The design of the boarding room reservation page for prospective tenants

Figure 15 is the design of the booking page that will appear when prospective tenants are interested in and intend to immediately book a boarding house. 


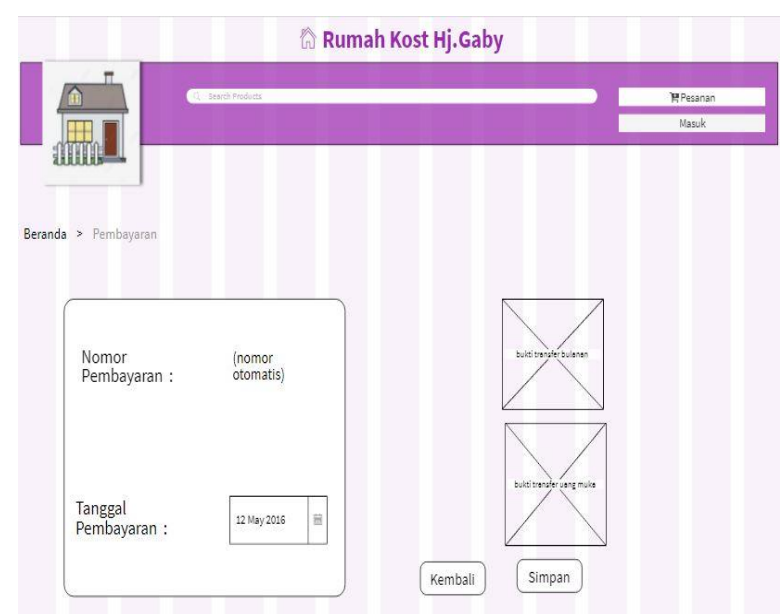

Figure 16. The design of the monthly boarding rental payment page along with the down payment

Figure 16 shows the payment page design for prospective tenants when entering proof of the down payment transfer and payment. Whereas for old boarding tenants, this page is used to enter proof of transfer of monthly boarding payments that they do.

\section{Testing and Substitution}

At this stage, tests will be carried out on each page of the website. The test will use the Black Box Testing method to see the output generated from input forms. Testing does not care about the correctness of the existing output. Performance testing was carried out using GTMetrix.com, the results were:

\section{Performance Scores}

\begin{tabular}{|l|l|}
\hline PageSpeed Score & YSlow Score \\
\hline$(83 \%) \bullet$ & A $(93 \%) \wedge$ \\
\hline
\end{tabular}

Figure 17. The results of testing the performance of the Hj.Gaby boarding house website with GTMetrix

Figure 17 shows the performance scores for the $\mathrm{Hj}$. Gaby Boarding House website outlined on the PageSpeed Score (83\%) and Yslow Score (93\%).

Figure 20. Description of the PageSpeed Score

Figure 20 outlines the 27 PageSpeed Score recommendations. A downward red sign indicates

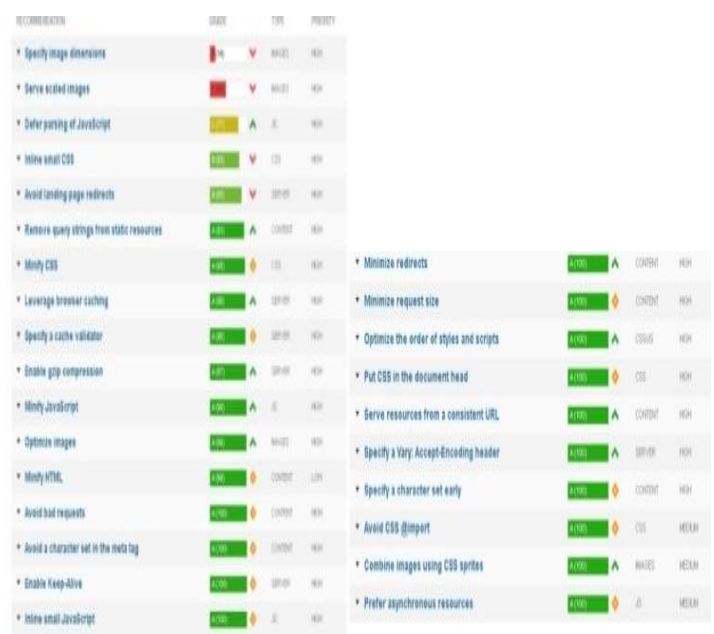

the performance of this website relative to other sites analyzed by GTMetrix in the past 30 days. Recommendations that have a red arrow require improvement, such as: specify image dimensions, serve scale images, inline small CSS, avoid landing page redirects.
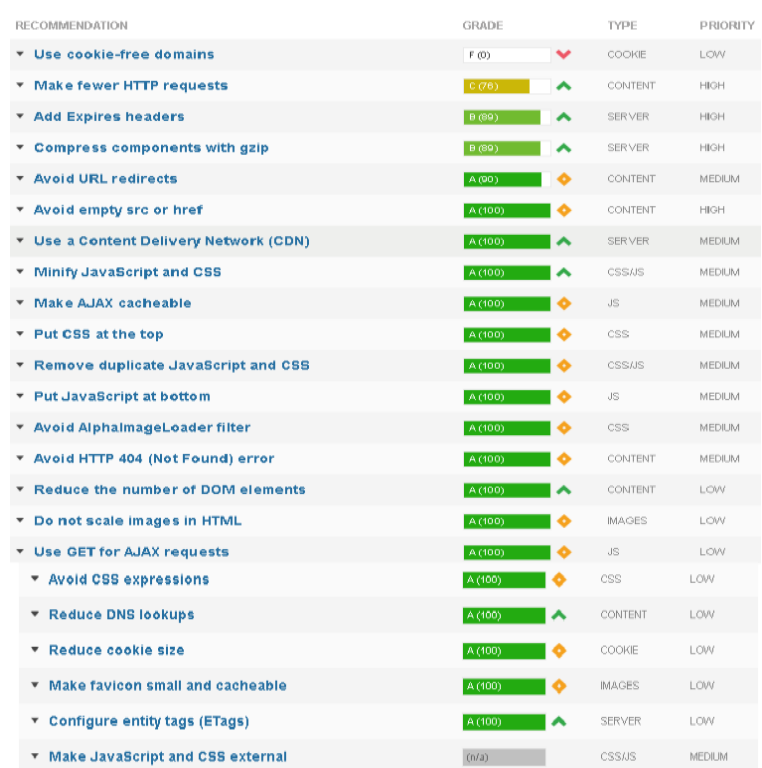

Figure 21. Description of the Yslow Score

Figure 21 outlines the 18 Yslow Score recommendations. Recommendations Use cookiefree domains has a red arrow that needs improvement to make the website even better. 
Table 1. Black Box Testing Results on the Registration Form

\begin{tabular}{|c|c|c|c|c|c|}
\hline No. & Test scenario & Test case & Expected results & Test result & Conclusion \\
\hline 1. & Enter a name & Name: Budi01 & $\begin{array}{l}\text { The system will reject and display } \\
\text { "enter characters without numbers or } \\
\text { special characters" }\end{array}$ & $\begin{array}{l}\text { According to } \\
\text { expectations }\end{array}$ & Valid \\
\hline 2. & Enter a name & Name: Budi & $\begin{array}{l}\text { The system will accept and the cursor } \\
\text { will move to the KTP number column }\end{array}$ & $\begin{array}{l}\text { According to } \\
\text { expectations }\end{array}$ & Valid \\
\hline 3. & $\begin{array}{l}\text { Enter the KTP } \\
\text { number }\end{array}$ & ID card number: $a b c$ & $\begin{array}{l}\text { The system will reject and display } \\
\text { "enter numbers, not letters or special } \\
\text { characters" }\end{array}$ & $\begin{array}{l}\text { According to } \\
\text { expectations }\end{array}$ & Valid \\
\hline 4. & $\begin{array}{l}\text { Enter the KTP } \\
\text { number }\end{array}$ & 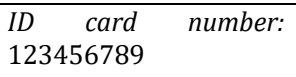 & $\begin{array}{l}\text { The system will accept and the cursor } \\
\text { will move to the Password field }\end{array}$ & $\begin{array}{l}\text { According to } \\
\text { expectations }\end{array}$ & Valid \\
\hline 1. & Enter the password & Password: 12345 & $\begin{array}{l}\text { The system will reject and display } \\
\text { "password must be } 6 \text { characters long" }\end{array}$ & $\begin{array}{l}\text { According to } \\
\text { expectations }\end{array}$ & Valid \\
\hline 2. & Enter the password & Password: 123456 & $\begin{array}{l}\text { The system will accept and the cursor } \\
\text { will move to the Password Again field }\end{array}$ & $\begin{array}{l}\text { According to } \\
\text { expectations }\end{array}$ & Valid \\
\hline 3. & $\begin{array}{l}\text { Enter the password } \\
\text { again }\end{array}$ & Password: 12345 & $\begin{array}{l}\text { The system will reject and display } \\
\text { "password must match" }\end{array}$ & $\begin{array}{l}\text { According to } \\
\text { expectations }\end{array}$ & Valid \\
\hline 4. & $\begin{array}{l}\text { Enter the password } \\
\text { again }\end{array}$ & Password: 123456 & $\begin{array}{l}\text { The system will accept and the cursor } \\
\text { will move to the address field }\end{array}$ & $\begin{array}{l}\text { According to } \\
\text { expectations }\end{array}$ & Valid \\
\hline 5. & $\begin{array}{l}\text { One of the data is } \\
\text { not completed }\end{array}$ & $\begin{array}{l}\text { Name: Budi } \\
\text { KTP Number: } \\
\text { 123456789 Again: } \\
\text { Password: } 123456 \\
\text { Password Number: } \\
\text { 123456 Address: (empty) } \\
\text { Phone N N } \\
\text { 123456789012 }\end{array}$ & $\begin{array}{l}\text { The system will reject and display } \\
\text { "Incomplete data" }\end{array}$ & $\begin{array}{l}\text { According to } \\
\text { expectations }\end{array}$ & Valid \\
\hline 6. & $\begin{array}{l}\text { All fields have been } \\
\text { filled in along with } \\
\text { the requested } \\
\text { photos, click the } \\
\text { "Register" button }\end{array}$ & $\begin{array}{l}\text { Name: Budi } \\
\text { KTP Number: } \\
\text { 123456789 } \\
\text { Password: } 123456 \\
\text { Password Again: } \\
\text { 123456 } \\
\text { Address: Jl.sulawesi } \\
\text { Phone Number: } \\
\text { 123456789012 }\end{array}$ & $\begin{array}{l}\text { The system will receive and display } \\
\text { "Data has been saved" }\end{array}$ & $\begin{array}{l}\text { According to } \\
\text { expectations }\end{array}$ & Valid \\
\hline
\end{tabular}

Black Box Testing is used to test the functionality of the system. Table 1 outlines the results of the Black Box Testing on the Registration Form. When filling in the name, KTP number, password code, and replenishing the password code with data that does not comply with the filling rules, the program turns out to refuse and notifies the correct filling rules. Likewise, when one of the data is not filled in, for example, address data, the program also provides notification to complete all requested data. All of these actions work as expected, as well as when data is filled in correctly and then saved.

\section{CONCLUSIONS AND SUGGESTIONS}

\section{Conclusion}

The design of this website-based system has resulted in several facilities for a down payment of boarding rent that must be input by prospective tenants after transferring to the boarding owner's account. Facilities to provide proof of transfer for monthly rental payments are also provided for old boarding tenants. These facilities are not provided by the current boarding rental website. However, this website is not based on Android so it still requires a browser to run it.

\section{Suggestion}

The author hopes that the Boarding Rental Information System that will be developed next can be based on Android so that it will make it easier for prospective boarders to access it.

\section{REFERENCE LIST}

Biantoro, J., \& Purnomo, D. (2017). The Causality Availability Of Food And Economic Growth In Central Java. Urecol Proceeding, February, 835-841. http://lpp.uad.ac.id/wpcontent/uploads/2017/05/107.-julibiantoro-835-841.pdf

Budiman, A., Wahyuni, L. S., \& Bantun, S. (2019). 
Perancangan Sistem Informasi Pencarian Dan Pemesanan Rumah Kos Berbasis Web (Studi Kasus: Kota Bandar Lampung). Jurnal Tekno Kompak, 13(2), https://doi.org/10.33365/jtk.v13i2.356

Fatkhudin, A., \& Novianti. (2015). Sistem informasi pemesanan rumah kost di kota pekalongan berbasis website. Surya Informatika, 1. https://doi.org/10.1007/s00198-011-1640-z

Hanafi. (2017). Konsep Penelitian R \& D Dalam Bidang Pendidikan. Saintifika Islamica: Jurnal Kajian Keislaman, 4(2), 129-150.

Haq, M. S. (2016). Pengembanagan Aplikasi Presensi Pegawai Berbasis Fingerprint. Jurnal Dinamika Manajemen Pendidikan, 1(1), 3440.

https://doi.org/10.26740/jdmp.v1n1.p34-40

Irnawati, O., \& Listianto, G. B. A. (2018). Metode Rapid Application Development (RAD) pada Perancangan Website Inventory Pt. Sarana Abadi Makmur Bersama (S.A.M.B) Jakarta. Evolusi: Jurnal Sains Dan Manajemen, 6(2), 12-18.

https://doi.org/10.31294/evolusi.v6i2.4414

Kusaeri, W. R., Juliana, P., \& Pratama, R. R. (2018). Perancangan Sistem Informasi Penjualan Menggunakan Metode Rapid Application Development (RAD) Di Pabrik Genteng Uun Super Jatiwangi. Prosiding SEMNASTEK 2018, 1-8.

https://jurnal.umj.ac.id/index.php/semnaste $\mathrm{k} /$ article/view/3457

Pressman, Roger S, P. . (2012). Rekayasa Perangkat Lunak (Pendekatan Praktisi) Edisi 7 - Buku 1 (1st ed.). Andi Offset.

Rachmawati, A. (2017). Membangun Informasi Layanan Umum Rumah Kos Melalui Aplikasi Berbasis Web. Jurnal Ilmiah FIFO, 9(2), 155. https://doi.org/10.22441/fifo.2017.v9i2.009

Ratnasari, D., Qur'ani, D. B., \& Apriani, A. (2018).
Sistem Informasi Pencarian Tempat Kos Berbasis Android. Jurnal INFORM, 3(1), 3245. https://doi.org/10.25139/ojsinf.v3i1.657

Sabirin, A. R., \& Sulfia, S. (2018). Sistem Informasi Jasa Pemesanan Kamar Kost Online Di Kota Baubau. Jurnal Informatika, 7(2), 1-5. http://www.ejournal.unidayan.ac.id/index.p hp/JIU/article/view/58

Sianturi, J. A., Piarsa, I. N., \& Purnawan, I. K. A. (2018). Aplikasi Pencarian dan Penyewaan Rumah Kost Berbasis Web dan Android. Jurnal Ilmiah Merpati (Menara Penelitian Akademika Teknologi Informasi), 6(3), 192203.

https://doi.org/10.24843/jim.2018.v06.i03.p 06

Sudiyono, S. (2015). Strategi Bertahan Hidup Nelayan P. Rimau Balak di Kabupaten Lampung Selatan. Jurnal Bina Praja: Journal of Home Affairs Governance, 7(3), 211-226. https://doi.org/10.21787/jbp.07.2015.211225

Susanti, N., Halin, H., \& Kurniawan, M. (2018). Pengaruh Bauran Pemasaran (4P) Terhadap Keputusanpembelian Perumahan PT. Berlian Bersaudara Propertindo. Jurnal Ilmiah Ekonomi Global Masa Kini, 8(1), 43-49. http://ejournal.uigm.ac.id/index.php/EGMK/ article/view/298

Syam, E. (2018). Rancang Bangun Sistem Informasi Rumah Kost Dan Kontrakan Teluk Kuantan. Jurnal Teknologi Dan Open Source, 1(1), 1-7. https://doi.org/10.36378/jtos.v1i1.2

Werdiningsih, H., Indrosaptono, D., \& Darmawan, E. (2015). Perubahan Tata Letak Ruang Rumah Tinggal Disepanjang Jalan Utama Lingkungan Dikaitkan Dengan Kegiatan Ekonomi. Modul, 51(2), $207=22$. https://doi.org/10.14710/mdl.15.2.2015.107 $-124$ 